\title{
In vitro Evaluation of Biofield Treatment on Viral Load Against Human Immunodeficiency-1 and Cytomegalo Viruses
}

\author{
Mahendra Kumar Trivedi ${ }^{1}$, Alice Branton ${ }^{1}$, Dahryn Trivedi $^{1}$, Gopal Nayak ${ }^{1}$, \\ Sambhu Charan Mondal ${ }^{2}$, Snehasis Jana ${ }^{2, *}$ \\ ${ }^{1}$ Trivedi Global Inc., Henderson, USA \\ ${ }^{2}$ Trivedi Science Research Laboratory Pvt. Ltd., Bhopal, Madhya Pradesh, India
}

Email address:

publication@trivedisrl.com (S. Jana)

\section{To cite this article:}

Mahendra Kumar Trivedi, Alice Branton, Dahryn Trivedi, Gopal Nayak, Sambhu Charan Mondal, Snehasis Jana. In vitro Evaluation of Biofield Treatment on Viral Load Against Human Immunodeficiency-1 and Cytomegalo Viruses. American Journal of Health Research. Vol. 3, No. 6, 2015, pp. 338-343. doi: 10.11648/j.ajhr.20150306.14

\begin{abstract}
Viral load quantification is the amount of particular viral DNA or RNA in a blood samples. It is one of the surrogate biomarker of AIDS. High viral load indicates that the immune system is failed to fight against viruses. The aim of this study was to evaluate the impact of biofield treatment on HIV-1 and HCMV in terms of viral loads as surrogate marker. The viral load assay was performed on stored stock cultures of HIV infected human plasma samples before and after 7 days of biofield treatment using Roche COBAS ${ }^{\circledR}$ AMPLICOR analyzer. Viral load (HIV-1 RNA and HCMV DNAaemia) was considered as surrogate marker for assessment of the impact of Mr. Trivedi's biofield treatment in HIV infected stored plasma samples. The viral load quantification of HIV-1 RNA in infected stored plasma samples was significantly reduced by $65 \%$ in biofield treated group as compared to control. Additionally, viral load of HCMV DNAaemia in infected stored plasma samples was also reduced by $80 \%$ in the biofield treated group as compared to control. Because, children are more prone to HCMV infection and adults are generally liable to suffer from HIV-1 infection. As the biofield treatment has reduced HCMV DNAaemia, it could be beneficial for HIV infected children populations. Altogether, data suggest that biofield treatment has significantly reduced the viral load quantification in HIV-1 and HCMV infected stored plasma samples and could be a suitable alternative treatment strategy for AIDS patients in near future.
\end{abstract}

Keywords: Human Immune Deficiency Virus, Biofield Treatment, Cytomegalo Virus, Viral Load, HIV RNA, HCMV DNAaemia, AIDS, Surrogate Biomarker

\section{Introduction}

Human immunodeficiency virus type 1 (HIV-1) is the main causative agent of acquired immune deficiency syndrome (AIDS) [1]. HIV is a worldwide pandemic disease, and the number of infected peoples around the world increasing day by day. Recent estimate from World Health Organization (WHO) shows that 16.3 million people have died from AIDS since the beginning of the epidemic. Currently, around 34.3 million people alive with HIV infection, in which approximately $7 \%$ are young adults [2], infected with HIV type 1 (HIV-1) across the mucosal surfaces or by direct inoculation. The virus first attacks to dendritic cells (DCs) and subsequently spreads to cluster of differentiation - $4\left(\mathrm{CD}^{4+}\right) \mathrm{T}$ lymphocytes [3]. Human cytomegalovirus (HCMV) is a vernacular name of the human herpes virus - 5, a highly host-specific virus of the herpesviridae family rarely causes symptoms. The target DNA sequence is specific, located within the HCMV DNA polymerase gene, and is not homologous to other members of the human herpes virus family. The pregnant women and immune weakened persons are highly prone to acquire infection by HCMV virus. It spreads through various body fluids, such as blood, urine, saliva, semen, and breast milk. It may also causes serious morbidity and mortality in organ transplant recipients, immunocompromised, HIV infected patients and congenitally infected newborns [4]. HCMV is mainly prevalent in kidney transplant patients. The viral 'threshold load' is very sensitive and specific for predicting 
both white blood cell and platelet quantification in kidney transplant patients. The threshold value is more than 10000 copies/mL considered as HCMV infection [5]. In infected adults, HIV viral load is predictive of progression to AIDS $[6,7]$ and HCMV DNAaemia predicts progression to disease, particularly retinitis [8]. Several study reports have confirmed the relation between HIV-1 viral load and HCMV DNAaemia levels in terms of prediction of disease (AIDS) progression in both adults [6, 7] and children $[9,10]$. Researchers found an excellent correlation between two viruses i.e. HIV infected adults are highly predictable for the development of HCMV end organ disease [11]. Hence, in this experiment the dual viruses were taken into consideration as a rational. Immunomodulatory therapies are currently used against HIV-1 infections which include mycophenolate mofetil, cyclosporine, interleukin-2 (IL-2), and various vaccines [12]. Although several treatment strategie are available against AIDS patients infected by HIV-1 such as antiretroviral agents and vaccination. But some difficulties are also present. Based on above lacunas, there is a need of an alternative way which may be useful to determine the viral loads by either enhancing the application of existing agents or by means of some alternative strategy or developing new drugs. Biofield treatment is an alternative approach which may be useful to improve these unfilled space associated with AIDS infected patients. Mr. Trivedi's unique biofield treatment (The Trivedi effect ${ }^{\circledR}$ ) has been extensively contributes in scientific communities in several fields [13-16]. Therefore, authors interested, to evaluate the impact of biofield treatment on viral load in HIV and HCMV infected plasma samples.

\section{Materials and Methods}

The viral samples (HIV-1 and HCMV) as stored stock cultures were procured from department of microbiology laboratory, P.D. Hinduja National Hospital and Medical Research Centre, Mumbai. The viral load assay was performed on HIV patients stored plasma samples before and after treatment using Roche COBAS AMPLICOR analyzer according to manufacturer's instructions.

\subsection{Biofield Treatment Strategy and Experimental Design}

Two sets of each viral samples (HIV-1; 31 samples and HCMV; 5 samples) of HIV and HCMV infected stored plasma were used in this experiment for determination of viral load quantification. The first sets of both viral samples were considered as control. No treatment was given to these sets. The second sets of both viral samples were subjected to Mr. Mahendra Trivedi's biofield treatment, considered as treated group. Both control and treated samples were analyzed after 7 days for viral load quantification in as per the standard protocols. An optimum precautionary measure was taken to maintain the cold chain throughout the experiment. The differences of viral load quantification before and after the treatment were noted.

\subsection{COBAS ${ }^{\circledR}$ Amplicor HIV-1 Monitor Test}

The COBAS $^{\circledR}$ amplicor HIV-1 monitor test (v1.5) is an in vitro nucleic acid amplification test approved by food and drug administration (FDA) for the quantification of HIV-1 RNA in human plasma on the COBAS AMPLICOR ${ }^{\mathrm{TM}}$ analyzer. This technique is a gold standard automated solution for testing of HIV-1 viral loads in major pharmaceutical trials [17].

\subsection{COBAS ${ }^{\circledR}$ Amplicor CMV Monitor Test}

The COBAS ${ }$ amplicor CMV monitor test is FDA approved in vitro amplification test for the quantification of HCMV DNA in human plasma on the COBAS AMPLICORTM analyzer. This is an automated, sensitive, reliable, and specific method for quantification of cytomegalo viral loads in HCMV infected patients with high productivity (600 copies/mL to 100,000 copies $/ \mathrm{mL}$ ) [18].

\section{Results and Discussion}

Viral load (Fig. 1) means the amount of HIV RNA or HCMV DNA particles per milliliter of blood sample. Higher the viral titer indicates that the immune system is failed to fight against HIV or HCMV.

The viral loads of HIV-1 and HCMV expressed as copies/ml are shown in Table 1 and 2, respectively. HIV RNA and HCMV DNA (viral load) and $\mathrm{CD}^{4+} \mathrm{T}$ lymphocyte cell count are the two surrogate markers of HIV patients [19].

All the values are expressed as (IU/mL); Serial number 131 denoted as viral stock human plasma samples.

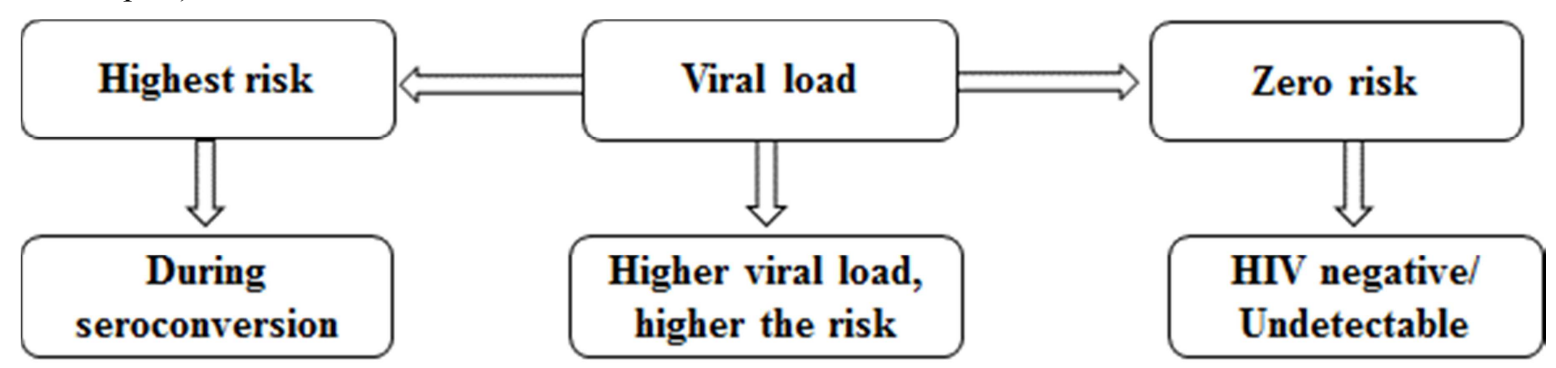

Figure 1. Schematic diagram related to viral load and its risk manifestation. 
Table 1. Viral load of human immunodeficiency virus type-1 (HIV-1) in infected stored plasma samples.

\begin{tabular}{|c|c|c|c|c|c|}
\hline S. No. & $\begin{array}{l}\text { Viral load } \\
\text { Control }\end{array}$ & Log10 (Control) & $\begin{array}{l}\text { Viral load } \\
\text { Treatment }\end{array}$ & Log10 (Treatment) & $\begin{array}{l}\text { Change in Viral Load Log10 } \\
\text { (Treatment) - Log10 (Control) }\end{array}$ \\
\hline 1. & 91900 & 4.96 & 18500 & 4.27 & -0.70 \\
\hline 2. & 179000 & 5.25 & 69300 & 4.84 & -0.41 \\
\hline 3. & 159000 & 5.20 & 121000 & 5.08 & -0.12 \\
\hline 4. & 10300 & 4.01 & 4110 & 3.61 & -0.40 \\
\hline 5. & 107000 & 5.03 & 103000 & 5.01 & -0.02 \\
\hline 6. & 1650000 & 6.22 & 3320000 & 6.52 & 0.30 \\
\hline 7. & 172000 & 5.24 & 122000 & 5.09 & -0.15 \\
\hline 8. & 7820 & 3.89 & 2320 & 3.37 & -0.53 \\
\hline 9. & 1540 & 3.19 & 3060 & 3.49 & 0.30 \\
\hline 10. & 34400 & 4.52 & 1320 & 3.12 & -1.40 \\
\hline 11. & 69300 & 4.84 & 174000 & 5.24 & 0.40 \\
\hline 12. & 2190 & 3.34 & 1760 & 3.25 & -0.09 \\
\hline 13. & 1860 & 3.27 & 881 & 2.94 & -0.32 \\
\hline 14. & 17400 & 4.24 & 8690 & 3.94 & -0.30 \\
\hline 15. & 216000 & 5.33 & 297000 & 5.47 & 0.14 \\
\hline 16. & 321000 & 5.51 & 440000 & 5.64 & 0.14 \\
\hline 17. & 17400 & 4.24 & 17400 & 4.24 & 0.00 \\
\hline 18. & 9840 & 3.99 & 8540 & 3.93 & -0.06 \\
\hline 19. & 10300 & 4.01 & 3140 & 3.50 & -0.52 \\
\hline 20. & 99200 & 5.00 & 65700 & 4.82 & -0.18 \\
\hline 21. & 1650000 & 6.22 & 2900000 & 6.46 & 0.24 \\
\hline 22. & 290000 & 5.46 & 291000 & 5.46 & 0.00 \\
\hline 23. & 156000 & 5.19 & 401000 & 5.60 & 0.41 \\
\hline 24. & 3070000 & 6.49 & 1450000 & 6.16 & -0.33 \\
\hline 25. & 587000 & 5.77 & 807000 & 5.91 & 0.14 \\
\hline 26. & 36500 & 4.56 & 22100 & 4.34 & -0.22 \\
\hline 27. & 138000 & 5.14 & 68400 & 4.84 & -0.30 \\
\hline 28. & 6560 & 3.82 & 4230 & 3.63 & -0.19 \\
\hline 29. & 1900000 & 6.28 & 2580000 & 6.41 & 0.13 \\
\hline 30. & 32800 & 4.52 & 20800 & 4.32 & -0.20 \\
\hline 31. & 42700 & 4.63 & 18600 & 4.27 & -0.36 \\
\hline
\end{tabular}

All the values are expressed as (IU/mL); Serial number 1-31 denoted as viral stock human plasma samples.

Table 2. Viral loads of human cytomegalo virus (HCMV) in infected stored plasma samples.

\begin{tabular}{|c|c|c|c|c|c|}
\hline \multirow{2}{*}{ S. No. } & Viral load & \multirow{2}{*}{ Log10 (Control) } & Viral load & \multirow{2}{*}{ Log10 (Treatment) } & \multirow{2}{*}{$\begin{array}{l}\text { Change in Viral Load Log10 } \\
\text { (Treatment) - Log10 (Control) }\end{array}$} \\
\hline & Control & & Treatment & & \\
\hline 1. & 86900 & 4.94 & 78200 & 4.89 & -0.05 \\
\hline 2. & 18100 & 4.26 & 8760 & 3.94 & -0.32 \\
\hline 3. & 40500 & 4.61 & 35000 & 4.54 & -0.06 \\
\hline 4. & 1570 & 3.20 & 1360 & 3.13 & -0.06 \\
\hline 5. & 697 & 2.84 & $<600$ & 2.78 & -0.07 \\
\hline
\end{tabular}

All the values are expressed as (IU/mL); Serial number 1-5 denoted as viral stock human plasma samples.

A. HIV-l Viral load

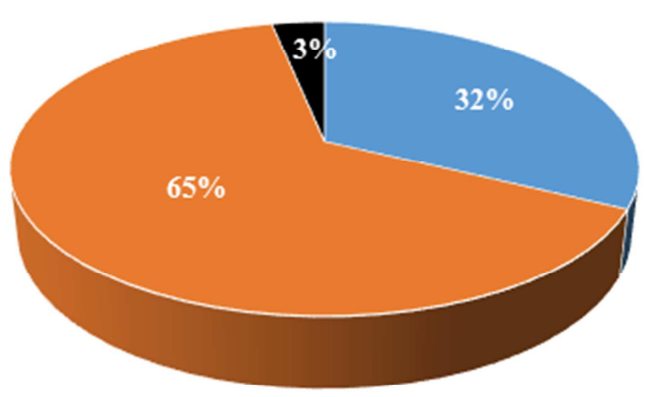

B. HCMV Viral load

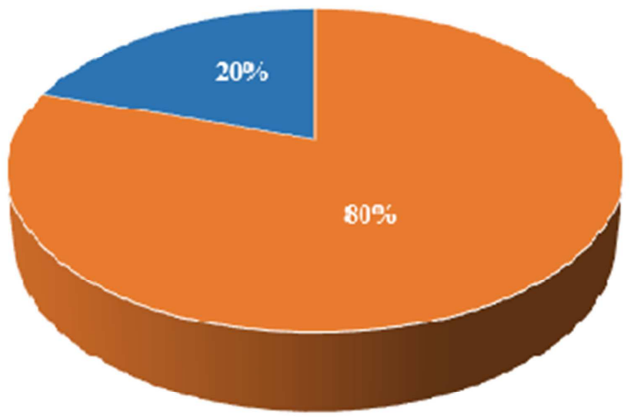

" \% Increased $\quad$ \% Decreased - No change

Figure 2. Percentage change of viral load of A. (HIV RNA) in human immunodeficiency virus type-1 (HIV-1) and B. (HCMV DNA) in human cytomegalo virus (HCMV) after biofield treatment. 
All the values are expressed as (IU/mL); Serial number 1-5 denoted as viral stock human plasma samples

In this experiment, vial load was considered as surrogate biomarker for assessment of the impact of Mr. Trivedi's biofield treatment. Study was carried out in total thirty one infected human stored plasma samples. The result showed that viral load of HIV RNA in infected plasma samples were reduced by $65 \%$ out of thirty one samples after biofield treatment as compared to control. In addition, viral load were increased by $32 \%$ in biofield treated group and $3 \%$ unchanged as compared to control (Figure 2A and 3).

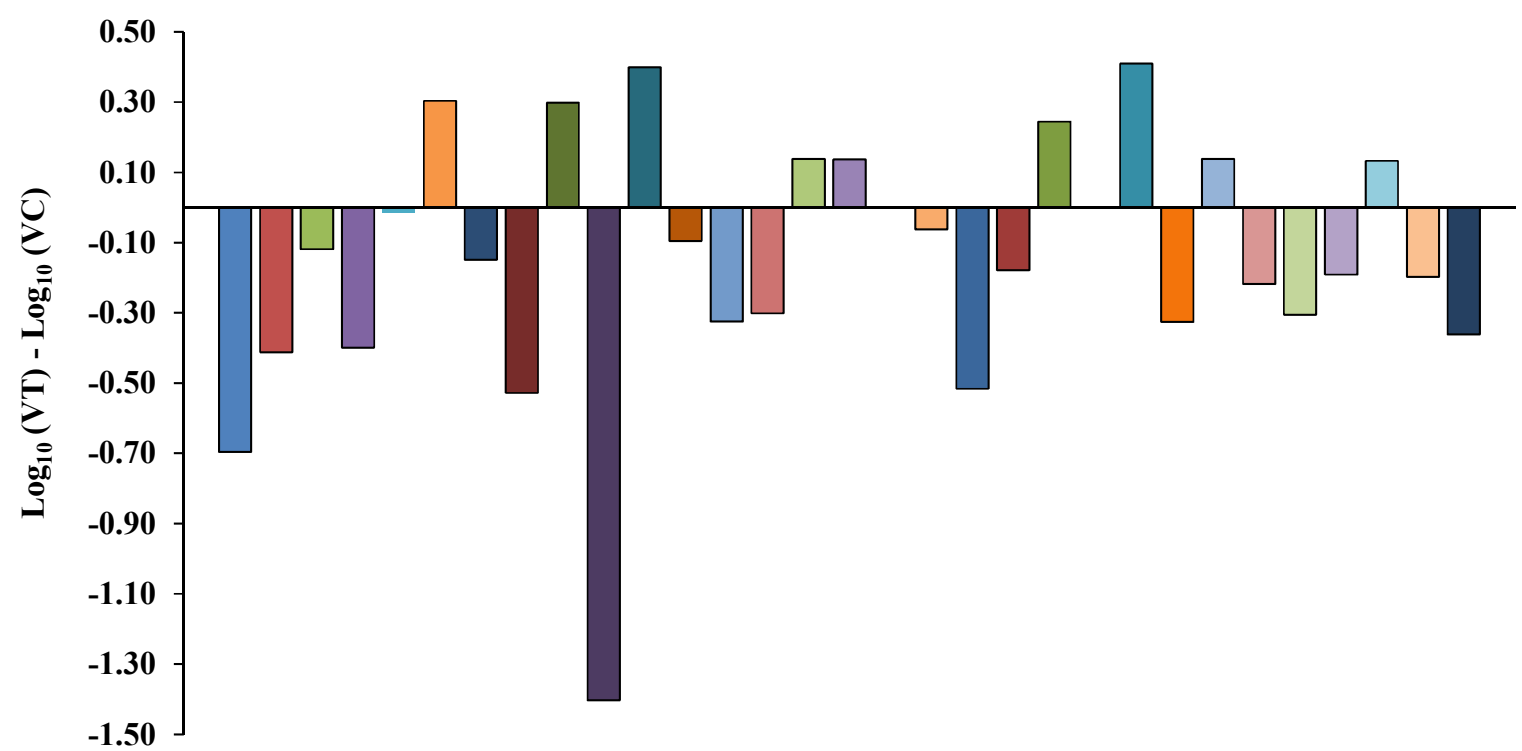

Figure 3. Difference in viral load of HIV RNA of 31 viral stock human plasma samples after biofield treatment. VT-Viral load in treatment (IU/mL); VC-Viral load in control (IU/mL).

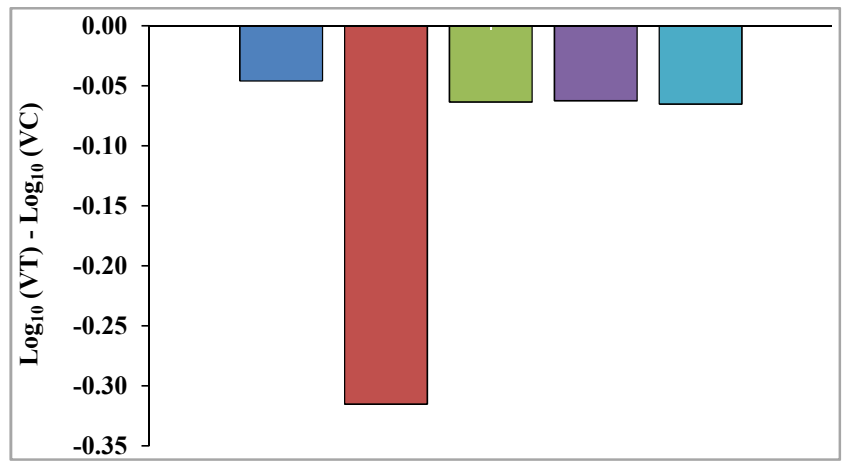

Figure 4. Difference in viral load of HCMV DNA of 5 viral stock human plasma samples after biofield treatment. VT- Viral load in treatment (IU/mL); VC-Viral load in control (IU/mL).

According to Greene et al. National Center for Complementary and Alternative Medicine (NCCAM), about 2000 reported that bioelectromagnetic based therapy i.e. biofield is used as an effective [20], and alternative therapy in HIV/AIDS infected patients [21]. This study findings also explored in pros of biofield treatment against HIV infections. This study further emphasized to HCMV that are responsible for progression of AIDS. Viral load quantification of HCMV DNA were determine in total five infected stored plasma samples. The results showed that viral load of HCMV DNA in infected stored plasma samples were significantly reduced by $80 \%$ after biofield treatment as compared to control. The study outcomes showed a significant improvement of biofield treatment. Besides, the viral load of HCMV DNA were increased by $0 \%$ and unable to detect about $20 \%$ in biofield treated group as compared to control (Figure 2B and 4).

Because, $20 \%$ of HCMV DNA are inactive not in multiplying state but infectious. Based on existing literatures, HCMV load in the plasma samples of HIV infected or AIDS patients is an important factor in the pathogenesis of retinitis [22]. Another study data indicates that the risk of HCMV disease and death occurs in AIDS patients is directly proportional to the quantity of HCMV DNA (viral load) in plasma, and the viral load quantification is a better predictor than $\mathrm{CD}^{4+} \mathrm{T}$ lymphocyte count [23]. The viral particles i.e. HIV RNA and HCMV DNA those are in multiplying state, possibly affected by Mr. Trivedi's biofield treatment. The specific frequencies of electromagnetic radiation which matches with the resonance frequencies of RNA or DNA, probably disintegrate the respective viral RNA/DNA and disrupted thus reduced the viable viral titer and vice versa $[24,25]$. According to a recent report regarding biofield treatment which was later approved by the German equivalent of the FDA emphasized that cancer patients have experienced healing with biofield treatment. Nowadays, many scientists and cutting edge practitioners believed that the secrets of regeneration and healing lie not only on costly medical drugs or expensive medical treatments, but also in the body's own Quantum Energy Biofield (QEB) [26]. Mr. Trivedi's biofield treatment has shown to improve overall productivity in the field of agriculture, biotechnology, 
material science and others field also, without utilization of any drugs. So, it is assumed that biofield treatment would be cost effective as compared to the existing treatment strategy.

Overall, the study data indicates that biofield treatment significantly reduced the viral load of HIV-1 and simultaneously eliminate the viral load of HCMV from infected human plasma samples. Based on the obtained results, it is presumed that biofield treatment could be novel, cost effective and an alternative advanced strategy towards AIDS patients.

\section{Conclusion}

To summarize, the study results showed significant $(65 \%)$ reduction of HIV RNA viral load from infected plasma samples in the biofield treated group. Experimental data also showed $80 \%$ elimination of HCMV DNAaemia from infected plasma samples after biofield treatment. It is assumed that Mr. Trivedi's biofield treatment could be beneficial to improve the viral loads in HIV-1 infected AIDS patients specially children with high level of HCMV DNAaemia.

\section{Acknowledgement}

The Authors gratefully acknowledged to Trivedi Science, Trivedi Testimonials and Trivedi Master Wellness and P.D. hinduja national hospital and medical research centre, Mumbai, India for their support.

\section{References}

[1] Buonaguro L, Tornesello ML, Buonaguro FM (2007) Human immunodeficiency virus type 1 subtype distribution in the worldwide epidemic: Pathogenetic and therapeutic implications. J Virol 81: 10209-10219.

[2] Janeway CA (2001) Immunobiology: The immune system in health and disease. (5thedn), New York, Garland Science.

[3] Kassutto S, Rosenberg ES (2004) Primary HIV type 1 infection. Clin Infect Dis 38: 1447-1453.

[4] Chakravarti A, Kashyap B, Matlani M (2009) Cytomegalovirus infection: An Indian perspective. Indian $\mathrm{J}$ Med Microbiol 27: 3-11.

[5] Eshraghi H, Hekmat R (2015) Which CMV viral load threshold should be defined as CMV infection in kidney transplant patients? Transplant Proc 47: 1136-1139.

[6] Mellors JW, Rinaldo CR, Gupta P, White RM, Todd JA, et al. (1996) Prognosis in HIV-1 infection predicted by the quantity of virus in plasma. Science 272: 1167-1170.

[7] Obrien WA, Hartigan PM, Martin D, Esinhart J, Hill A, et al. (1996) Changes in plasma HIV-1 RNA and $\mathrm{CD}^{4+}$ lymphocyte counts and the risk of progression to AIDS. Veterans affairs cooperative study group on AIDS. N Engl J Med 334: 426-431.

[8] Spector SA, Merrill R, Wolf D, Daukner WM (1992)
Detection of human cytomegalovirus in plasma of AIDS patients during acute visceral disease by DNA amplification. J Clin Microbiol 30: 2359-2365.

[9] Palumbo PE, Kwok S, Waters S, Wesley Y, Lewis D, et al. (1995) Viral measurement by polymerase chain reaction-based assays in human immunodeficiency virus-infected infants. J Pediatr 126: 592-595.

[10] McIntosh K, Shevitz A, Zaknun D, Kornegay J, Chatis P, et al. (1996) Age and time-related changes in extracellular viral load in children infected with human immunodeficiency virus. Pediatr Infect Dis J 15: 1087-1091.

[11] Boriskin Y, Sharland M, Dalton R, duMont G, Booth J, et al. (1999) Viral loads in dual infection with HIV-1 and cytomegalovirus. Arch Dis Child 80: 132-136.

[12] Lane HC (1989) The role of immunomodulators in the treatment of patients with AIDS. AIDS 3: S181-S185.

[13] Trivedi MK, Tallapragada RM, Branton A, Trivedi D, Nayak G, et al. (2015) Characterization of physical, spectral and thermal properties of biofield treated 1,2,4-Triazole. J Mol Pharm Org Process Res 3: 128.

[14] Shinde V, Sances F, Patil S, Spence A (2012) Impact of biofield treatment on growth and yield of lettuce and tomato. Aust J Basic Appl Sci 6: 100-105.

[15] Sances F, Flora E, Patil S, Spence A, Shinde V (2013) Impact of biofield treatment on ginseng and organic blueberry yield. Agrivita J Agric Sci 35.

[16] Nayak G, Altekar N (2015) Effect of biofield treatment on plant growth and adaptation. J Environ Health Sci 1: 1-9.

[17] Berger A, Scherzed L, Sturmer M, Preiser W, Doerr HW, et al. (2002) Evaluation of the Cobas AmpliPrep/Cobas Amplicor HIV-1 Monitor Ultrasensitive Test: Comparison with the Cobas Amplicor HIV-1 Monitor test (manual specimen preparation). J Clin Virol 25: S103-S107.

[18] Irene GS, Jennie AW, Mark JE, Carlos VP (2000) Thomas FS evaluation of the COBAS AMPLICOR CMV MONITOR Test for detection of viral DNA in specimens taken from patients after liver transplantation. J Clin Microbiol 38: 600-606.

[19] Murray JS, Elashoff MR, Iacono-Connors LC, Cvetkovich TA, Struble KA (1999) The use of plasma HIV RNA as a study endpoint in efficacy trials of antiretroviral drugs. AIDS. 13: 797-804.

[20] Ernst E (1997) Complementary AIDS therapies: The good, the bad and the ugly. Int J STD AIDS 8: 281-285.

[21] Kirksey KM, Goodroad BK, Kemppainen JK, Holzemer LW, Bunch EH, et al. (2002) Complementary therapy use in persons with HIV/AIDS. J Holist Nurs 20: 264-278.

[22] Bowen EF, Wilson P, Cope A, Sabin C, Griffiths P, et al. (1996) Cytomegalovirus retinitis in AIDS patients: influence of cytomegaloviral load on response to ganciclovir, time to recurrence and survival. AIDS 10: 1515-1520.

[23] Spector SA, Wong R, Hsia K, Pilcher M, Stempien MJ (1998) Plasma cytomegalovirus (CMV) DNA load predicts CMV disease and survival in AIDS patients. J Clin Invest 101: 497502 . 
[24] Yu ZG, Song X (2001) Variable range hopping and electrical conductivity along the DNA double helix. Phys Rev Lett 86: 6018 .

[25] Tran P, Alavi B, Grunen G (2000) Charge transport along the lambda DNA double helix. Phys Rev Lett 85: 1564-1567.
[26] Marshall RJ The best kept secret in nutrition: The body's biofield communication system. Premier research labs. Austin, TX 78667. 